\title{
Phylogenetic position and emended description of the genus Methylovorus
}

Correspondence

Yuri A. Trotsenko

trotsenko@ibpm.pushchino.ru

\author{
Nina V. Doronina, Ekaterina G. Ivanova and Yuri A. Trotsenko \\ G. K. Skryabin Institute of Biochemistry and Physiology of Microorganisms, Russian Academy \\ of Sciences, Pushchino, Moscow region, 142290, Russia
}

\begin{abstract}
The genus Methylovorus, currently represented by the restricted facultative methylotroph Methylovorus glucosotrophus Govorukhina and Trotsenko 1991 and the obligate methylotroph Methylovorus mays Doronina et al. 2001, is here established by direct sequencing of amplified $16 S$ rRNA genes and DNA-DNA hybridization to be clearly separated from the extant ribulose monophosphate (RuMP) pathway methylobacteria and to form a distinct branch within the $\beta$-Proteobacteria.
\end{abstract}

To date, four genera have been described for the group of obligately and restricted facultatively methylotrophic bacteria (methylobacteria) with the ribulose monophosphate (RuMP) pathway of $\mathrm{C}_{1}$ assimilation: Methylophaga (Janvier et al., 1985; de Zwart et al., 1996; Doronina et al., 2003a, b), Methylobacillus (Yordy \& Weaver, 1977; Urakami \& Komagata, 1986), Methylophilus (Jenkins et al., 1987) and Methylovorus (Govorukhina \& Trotsenko, 1991).

The genus Methylovorus was proposed for restricted facultative methylobacteria isolated from activated sludge, mud, soil and pond water. On the basis of some phenetic characteristics and DNA-DNA relatedness, five isolates were described as one species, Methylovorus glucosotrophus. Another restricted facultative methylotroph, Methylovorus sp. strain SS1, was isolated from Malaysian soil samples (Seo \& Kim, 1993) but not identified to the species level. More recently, we isolated from maize phyllosphere an obligate methylotroph which was classified as the novel species Methylovorus mays (Doronina et al., 2000, 2001). It synthesized phytohormones, cytokinins and auxins (Ivanova et al., 2000, 2001), and exerted a beneficial effect on the in vitro growth and morphogenesis of plants (Kalyaeva et al., 2001). More recently, we also demonstrated that Methylovorus glucosotrophus $6 \mathrm{~B} 1^{\mathrm{T}}$ is able to produce indole-3-acetic acid (Doronina et al., 2002). In the light of these novel results, it seems reasonable to revise the formal description of the genus Methylovorus. Besides, the phylogenetic position of the Methylovorus species was not previously investigated. Here, we report some novel

Published online ahead of print on 18 November 2004 as DOI 10.1099/ijs.0.63111-0.

Abbreviation: RuMP, ribulose monophosphate.

The GenBank/EMBL/DDBJ accession numbers for the 16S rRNA gene sequences of strains $6 B 1^{\top}$ and $C^{\top}$ are respectively AY486133 and AY486132. characteristics and phylogenetic analysis of the genus Methylovorus.

DNA of Methylovorus glucosotrophus $6 \mathrm{~B}^{\mathrm{T}} \quad(=\mathrm{ATCC}$ $\left.49758^{\mathrm{T}}\right)$ and Methylovorus mays $\mathrm{C}^{\mathrm{T}}\left(=\operatorname{NCIMB} 13992^{\mathrm{T}}\right)$ was isolated and purified according to Marmur (1961) and the 16S rRNA genes were amplified and sequenced (Lane, 1991). The determined 16S rRNA gene sequences were aligned against those of representative taxa of methylobacteria by using the CLUSTAL program. Positions of sequence uncertainty were omitted; in total, 1415 nucleotides were used in the analysis. Phylogenetic relationships were determined by the neighbour-joining method and the programs of the TREECON package (Van de Peer \& De Wachter, 1994), by maximum-likelihood by using the PUZZLE program (Strimmer \& von Haeseler, 1996) and by maximum-parsimony using the program DNAPARS from the PHYLIP package (Felsenstein, 1989) with bootstrap analysis of 100 trees.

The sequences were compared to representatives of the $\alpha$-, $\beta$ - and $\gamma$-subclasses of the Proteobacteria, including the methylotrophic genera with validly published names. In preliminary trials, a total of 98 sequences were used and several phylogenetic trees were generated. The phylogenetic analyses employed different algorithms, with similar results. According to $16 \mathrm{~S}$ rRNA gene sequence analysis, strains $6 \mathrm{~B} 1^{\mathrm{T}}$ and $\mathrm{C}^{\mathrm{T}}$ were closely related, with a similarity level of $98.9 \%$. The highest degree of similarity was found to species of Methylophilus (92.6-94.3\%) and Methylobacillus $(92 \cdot 1-94 \cdot 3 \%)$ (Fig. 1 ). Thus, strains $6 \mathrm{~B}^{\mathrm{T}}$ and $\mathrm{C}^{\mathrm{T}}$ are phylogenetically separated from other representatives of the $\beta$-Proteobacteria at the generic level. Moreover, the level of DNA-DNA relatedness between Methylovorus glucosotrophus $6 \mathrm{~B}^{\mathrm{T}}$ and Methylovorus mays $\mathrm{C}^{\mathrm{T}}$ was $56 \%$. However, they had a very low degree of DNA-DNA hybridization (5-8\%) with Methylophilus methylotrophus NCIMB $10515^{\mathrm{T}}$ and Methylobacillus glycogenes ATCC 


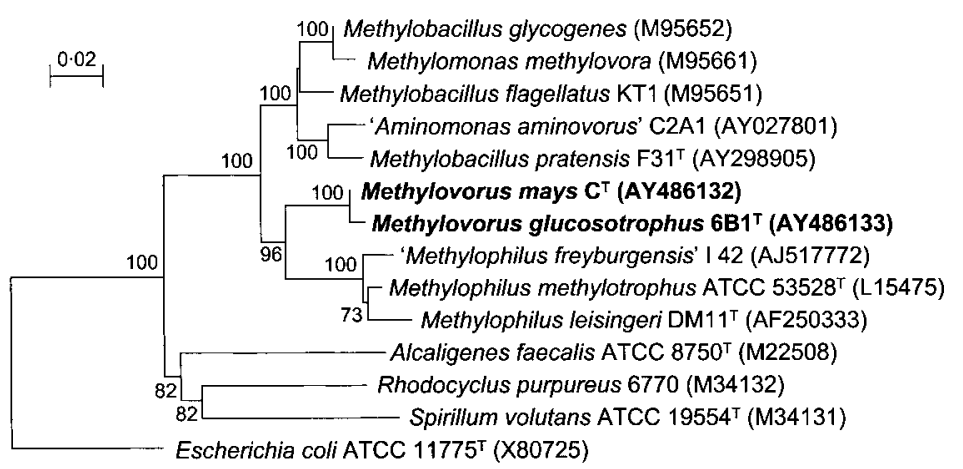

Fig. 1. Phylogenetic position of Methylovorus glucosotrophus $6 \mathrm{~B}^{\top}$ and Methylovorus mays $\mathrm{C}^{\top}$ among related micro-organisms based on 16S rRNA gene sequences. Pairwise evolutionary distances were computed by the JukesCantor correction using programs of PHYLIP (version 3.5) package. Escherichia coli ATCC $11775^{\top}$ (X80725) was used as an outgroup. Bar, $2 \%$ evolutionary difference. Numbers at branch points are bootstrap values from 100 replicates.

$29475^{\mathrm{T}}$. DNA-DNA hybridization was carried out according to the method of Denhardt (1966).

Major differential characteristics of the RuMP-pathway obligate and restricted facultative methylobacteria are summarized in Table 1.

\section{Emended description of the genus Methylovorus Govorukhina and Trotsenko 1991}

Methylovorus [Me.thy.lo.vo'rus. N.L. n. methyl the methyl radical; N.L. masc. adj. vorus (sic) consuming; N.L. masc. n. Methylovorus (sic) the methyl-consumer].

Gram-negative rods, $0 \cdot 4-0 \cdot 6 \times 1 \cdot 0-1 \cdot 4 \mu \mathrm{m}$. Motile by a single polar flagellum. Do not form endospores or complex intracellular membranes, either sheath or prosthecae. Some strains produce slime. Multiply by binary fission. No aggregation or pigmentation in liquid medium. Colonies on methanol/mineral salt agar incubated for 2 days at $30^{\circ} \mathrm{C}$ are circular, $1-2 \mathrm{~mm}$ in diameter, with entire edges, convex and translucent to opaque, creamy or milky in colour. No growth or very poor growth on nutrient agar and in nutrient broth at $30-40{ }^{\circ} \mathrm{C}$. No growth under an atmosphere of $\mathrm{CH}_{4}+\mathrm{O}_{2}$ or $\mathrm{H}_{2}+\mathrm{CO}_{2}+\mathrm{O}_{2}$. No growth in the presence of $3 \%(\mathrm{w} / \mathrm{v}) \mathrm{NaCl}$. Optimal $\mathrm{pH}$ for growth, $7 \cdot 0-7 \cdot 5$, and temperature, $35-40{ }^{\circ} \mathrm{C}$. Strictly aerobic with respiratory metabolism. Obligate or restricted facultative methylotrophs. Utilize methanol as the carbon and energy source. Some strains can grow poorly on methylated amines and glucose. Nitrates, ammonium salts, methylated amines and glutamate serve as nitrogen sources. Acetoin, $\mathrm{H}_{2} \mathrm{~S}$ and $\mathrm{NH}_{3}$ are not produced in test medium. Urease-, catalaseand oxidase-positive. Peroxidase is variable. Do not degrade cellulose, gelatin or Tween 80. Indole is formed from Ltryptophan in mineral medium with methanol as the sole carbon and energy source and with $\mathrm{KNO}_{3}$ as a nitrogen source. Ammonium ions inhibit tryptophan deamination. Assimilate $\mathrm{C}_{1}$ compounds through the RuMP pathway (Entner-Doudoroff variant) and ammonia via the glutamate cycle (glutamate synthase and glutamine synthetase). Neither $\alpha$-ketoglutarate dehydrogenase nor the glyoxylate shunt enzymes are present. 6-Phosphogluconate dehydrogenase is specific for $\mathrm{NAD}^{+}$(not NADP). The prevailing cellular fatty acids are $\mathrm{C}_{16: 0}$ and $\mathrm{C}_{16: 1} \omega \mathrm{T}$. The major ubiquinone is $\mathrm{Q}_{8}$. The dominant phospholipids are phosphatidylethanolamine, phosphatidylglycerol and diphosphatidylglycerol (cardiolipin). Belong to the $\beta$-subclass of the Proteobacteria. Habitat: activated sludge, mud, soil,

Table 1. Major differential characteristics of obligate and restricted facultative methylobacteria with the RuMP pathway of $\mathrm{C}_{1}$ assimilation

Members of all four genera exhibit $\mathrm{NAD}^{+}$-specific isocitrate dehydrogenase activity. GS/GOGAT, Glutamine synthetase/glutamate synthase.

\begin{tabular}{|c|c|c|c|c|}
\hline Characteristic & Methylovorus & Methylophilus & Methylobacillus & Methylophaga \\
\hline DNA G $+C$ content $(\mathrm{mol} \%)$ & $56-58$ & $50-53$ & $53-62$ & $38-49$ \\
\hline Growth at $3 \%(\mathrm{w} / \mathrm{v}) \mathrm{NaCl}$ & - & - & - & + \\
\hline Ammonia assimilation & GS/GOGAT & GS/GOGAT & $\begin{array}{c}\text { Glutamate } \\
\text { dehydrogenase }\end{array}$ & $\begin{array}{c}\text { Glutamate dehydrogenase, } \\
\text { GS/GOGAT }\end{array}$ \\
\hline Diphosphatidylglycerol & + & - & + & + \\
\hline Optimal growth temperature $\left({ }^{\circ} \mathrm{C}\right)$ & $35-40$ & $30-37$ & $29-42$ & $25-32$ \\
\hline Subclass of Proteobacteria & $\beta$ & $\beta$ & $\beta$ & $\gamma$ \\
\hline
\end{tabular}


pond water and plants. The $\mathrm{G}+\mathrm{C}$ content of the DNA is $56-58 \mathrm{~mol} \%\left(T_{\mathrm{m}}\right)$. The type species is Methylovorus glucosotrophus Govorukhina and Trotsenko 1991.

\section{Emended description of Methylovorus glucosotrophus Govorukhina and Trotsenko 1991}

Methylovorus glucosotrophus [glu.cos.o.tro'phus. N.L. n. glucosum glucose; Gr. adj. trophikos nursing, tending or feeding; N.L. masc. adj. glucosotrophus (sic) feeding on glucose].

Morphology and general characteristics are as given for the genus. Growth is possible at $20-45^{\circ} \mathrm{C}$ and $\mathrm{pH} 6 \cdot 5-8 \cdot 5$, with optima at $35-37^{\circ} \mathrm{C}$ and $\mathrm{pH} 7 \cdot 2$. Restricted facultative methylotroph. Methanol and glucose are used as sole carbon and energy sources. Generation times when grown on methanol and glucose are respectively 2 and $17 \mathrm{~h}$. No vitamins or any additional growth factors are required. Hydrolyses starch. The $\mathrm{G}+\mathrm{C}$ content of the DNA is $55 \cdot 8 \mathrm{~mol} \%\left(T_{\mathrm{m}}\right)$.

The type strain, strain $6 \mathrm{~B}^{\mathrm{T}}$ (=ATCC $49758^{\mathrm{T}}=\mathrm{VKM} \mathrm{B}$ $1745^{\mathrm{T}}=$ NCIMB $\left.13222^{\mathrm{T}}\right)$, was isolated from wastewaters in Alma-Ata (Kazakhstan). The GenBank accession number for the 16S rRNA gene sequence of the type strain is AY486133.

\section{Emended description of Methylovorus mays Doronina et al. 2001}

Methylovorus mays (mays. N.L. n. mays maize, the name of the host plant Zea mays L.).

Morphology and general characteristics are as given for the genus. Growth is possible at $20-45^{\circ} \mathrm{C}$ and $\mathrm{pH} 6 \cdot 5-8 \cdot 5$, with optima at $35-40^{\circ} \mathrm{C}$ and $\mathrm{pH} 7 \cdot 0-7 \cdot 5$. Obligate methylotroph utilizing methanol as the sole carbon and energy source. Generation time is $2 \mathrm{~h}$. No vitamins or additional growth factors are required. Does not hydrolyse starch. Phytosymbiont producing phytohormones: cytokinins (zeatin and zeatine riboside) and auxins (indole-3-acetic acid and indole-3-lactic acid). Promotes germination of seeds and stimulates plant growth and morphogenesis. The $\mathrm{G}+\mathrm{C}$ content of the DNA is $57 \cdot 2 \mathrm{~mol} \%\left(T_{\mathrm{m}}\right)$.

The type strain, strain $\mathrm{C}^{\mathrm{T}}\left(=\mathrm{VKM} B-2221^{\mathrm{T}}=\mathrm{NCIMB}\right.$ $\left.13922^{\mathrm{T}}\right)$, was isolated from the phyllosphere of Zea mays L. in Moscow region (Russia). The GenBank accession number for the 16S rRNA gene sequence of the type strain is AY486132.

\section{Acknowledgements}

This work was supported by grant RFBR 03-04-49166. The authors wish to thank anonymous reviewers for their valuable comments and remarks.

\section{References}

de Zwart, J. M. M., Nelisse, P. N. \& Kuenen, J. G. (1996). Isolation and characterization of Methylophaga sulfidovorans sp. nov.: an obligately methylotrophic, aerobic, demethylsulfide oxidizing bacterium from a microbial mat. FEMS Microbiol Ecol 20, 261-270.

Denhardt, D. T. (1966). A membrane-filter technique for the determination of complementary DNA. Biochem Biophys Res Commun 23, 641-646.

Doronina, N. V., Kudinova, L. V. \& Trotsenko, Yu. A. (2000). Methylovorus mays sp. nov.: a new species of aerobic, obligately methylotrophic bacteria associated with plants. Microbiology (English translation of Mikrobiologiya) 69, 599-603.

Doronina, N. V., Kudinova, L. V. \& Trotsenko, Yu. A. (2001). Methylovorus mays sp. nov. In Validation of the Publication of New Names and New Combinations Previously Effectively Published Outside the IJSEM, List no. 82. Int J Syst Evol Microbiol 51, 1619-1620.

Doronina, N. V., Ivanova, E. G. \& Trotsenko, Y. A. (2002). New evidence for the ability of methylobacteria and methanotrophs to synthesize auxins. Microbiology (English translation of Mikrobiologiya) 71, 116-118.

Doronina, N. V., Darmaeva, T. D. \& Trotsenko, Y. A. (2003a). Methylophaga alcalica sp. nov., a novel alkaliphilic and moderately halophilic, obligately methylotrophic bacterium from an East Mongolian saline soda lake. Int J Syst Evol Microbiol 53, 223-229.

Doronina, N. V., Darmaeva, T. D. \& Trotsenko, Y. A. (2003b). Methylophaga natronica sp. nov., a new alkaliphilic and moderately halophilic, restricted-facultatively methylotrophic bacterium from soda lake of the Southern Transbaikal region. Syst Appl Microbiol 26, 382-389.

Felsenstein, J. (1989). PHYLIP - phylogenic inference package (version 3.2). Cladistics 5, 164-166.

Govorukhina, N. I. \& Trotsenko, Y. A. (1991). Methylovorus, a new genus of restricted facultatively methylotrophic bacteria. Int J Syst Bacteriol 41, 158-162.

Ivanova, E. G., Doronina, N. V., Shepelyakovskaya, A. O., Laman, A. G., Brovko, F. A. \& Trotsenko, Yu. A. (2000). Facultative and obligate aerobic methylobacteria synthesize cytokinins. Microbiology (English translation of Mikrobiologiya) 69, 646-651.

Ivanova, E. G., Doronina, N. V. \& Trotsenko, Yu. A. (2001). Aerobic methylobacteria synthesize auxins. Microbiology (English translation of Mikrobiologiya) 70, 392-397.

Janvier, M., Frehel, C., Grimont, F. \& Gasser, F. (1985). Methylophaga marina gen. nov., sp. nov. and Methylophaga thalassica sp. nov., marine methylotrophs. Int J Syst Bacteriol 35, 131-139.

Jenkins, O., Byrom, D. \& Jones, D. (1987). Methylophilus: a new genus of methanol-utilizing bacteria. Int J Syst Bacteriol 37, 446-448.

Kalyaeva, M. A., Zakharchenko, N. S., Doronina, N. V., Rukavtsova, E. B., Ivanova, E. G., Alekseeva, V. V., Trotsenko, Yu. A. \& Bur'yanov, Ya. I. (2001). Plant growth and morphogenesis in vitro is promoted by associative methylotrophic bacteria. Russian J Plant Physiol (English translation of Fiziol Rast) 48, 514-517.

Lane, D. J. (1991). 16S/23S rRNA sequencing. In Nucleic Acid Techniques in Bacterial Systematics, pp. 115-175. Edited by E. Stackebrandt \& M. Goodfellow. Chichester: Wiley.

Marmur, J. A. (1961). A procedure for the isolation of deoxyribonucleic acid from microorganisms. J Mol Biol 3, 208-214.

Seo, S. A. \& Kim, Y. M. (1993). Isolation and characterization of a restricted facultatively methylotrophic bacterium Methylovorus sp. strain SS1. Kor J Microbiol 31, 179-183. 
Strimmer, K. \& von Haeseler, A. (1996). Quartet puzzling: a quartet maximum-likelihood method for reconstructing tree topologies. Mol Biol Evol 13, 964-969.

Urakami, T. \& Komagata, K. (1986). Emendation of Methylobacillus Yordy and Weaver 1977, a genus for methanol-utilizing bacteria. Int J Syst Bacteriol 36, 502-511.
Van de Peer, Y. \& De Wachter, R. (1994). TREECON for Windows: a software package for the construction and drawing of evolutionary trees for the Microsoft Windows environment. Comput Appl Biosci 10, 569-570.

Yordy, J. R. \& Weaver, T. L. (1977). Methylobacillus: a new genus of obligately methylotrophic bacteria. Int J Syst Bacteriol 27, 247-255. 